УДК 657.05:342.7

Fatenok-Tkachuk Alla, Ph.D., Associate Professor, Lesya Ukrayinka Volyn National University, The Department of Accounting and Taxation, Lutsk, ORCID ID: 0000-0001-6200-4873, allafat@i.ua

Akymenko Olena, Ph.D., Associate Professor, National University of Chernihiv Polytechnic, Cherkasy, ORCID ID: 0000-0002-0323-5978 elena.akymenko@gmail.com ,

Gavrilyuk Zoryana, student of Lesya Ukrayinka Volyn National University, Lutsk, ORCID ID: 0000-0002-2410-7668 zorianagavriluk@ukr.net,

https://doi.org/10.29038/2786-4618-2021-04-48-55

\title{
ACCOUNTING AND ANALYTICAL SUPPORT OF REGISTRATION OF OWNERSHIP RIGHT FOR INNOVATION PRODUCT
}

Abstract. Intellectual property objects are the driving force in the development of science and technology. The problem of accounting of intellectual property objects in the context of attribution of authorship on someone else's development and application of effective means of protection of innovation product in conditions of unfair competition is actualized. The main task of the enterprise innovation development is to form its accounting and analytical support, which should help to expand the possibilities of forming and using their innovative potential, that is why the work is urgent and timely. Systematized accounting accounts and typical holding, which can be used for purchase and sale of licenses. The analysis of introduced innovations and patents was carried out. The reasons of decrease of the number of registered objects of intellectual property were revealed. The focus is on know-how as an object of intangible assets and the main forms of documentary confirmation of the introduction and disposal OF the object ON are systematized. Methodological recommendations on patent registration have been developed.

Key words. Intellectual property, invention, useful model, know-how, patenting, license.

Фатенок-Ткачук Алла, кандидат экономических наук, доцент, Волынский национальный университет имени Леси Украинки, кафедра учета и налогооблоджения г. Луцк

Акименко Елена, кандидат экономических наук, доцент, Национальный университет Черниговская политехника, г. Чернигов,

Гаврилюк Зоряна, студентка,

Волынский национальный университет имени Леси Украинки, г. Луцк 


\title{
УЧЕТНО-АНАЛИТИЧЕСКОЕ ОБЕСПЕЧЕНИЕ РЕГИСТРАЦИИ ПРАВА СОБСТВЕННОСТИ НА ИННОВАЦИОННЫЙ ПРОДУКТ
}

\begin{abstract}
Аннотация. Объекты интеллектуальной собственности являются движущей силой в развитии науки и технологий. Актуализирована проблематика учета объектов интеллектуальной собственности в контексте присвоения авторства на чужие разработки и применение эффективных средств защиты инновационного продукта в условиях недобросовестной конкуренции. Основной задачей активизации инновационного развития предприятия является формирование его учетно-аналитического обеспечения, которое должно способствовать расширению возможностей формирования и использования их инновационного потенциала, поэтому работа актуальна и своевременно. Систематизированы счета бухгалтерского учета и типовые проводки, которые могут использоваться при купле-продаже лицензий. Проведен анализ внедренных инноваций и выданных патентов. Выявлены причины уменьшения количества зарегистрированных объектов интеллектуальной собственности. Сосредоточено внимание на ноу-хау как объекте нематериального актива и систематизированы основные формы документального подтверждения ввода и выбытия объекта НА. Сформированы методические рекомендации по учету патентов.
\end{abstract}

Ключевые слова. Интеллектуальная собственность, изобретение, полезная модель, ноу-хау, патентование, лицензия.

Фатенок-Ткачук Алла, кандидат економічних наук, доцент, Волинський національний університет імені Лесі Українки, м. Луцьк Акименко Олена,
кандидат економічних наук, доцент,
Національний університет Чернігівська політехніка,
м. Чернігів

Гаврилюк Зоряна, Студентка, Волинський національний університет імені Лесі Українки, м. Луцьк

\section{ОБЛІКОВО-АНАЛІТИЧНЕ ЗАБЕЗПЕЧЕННЯ РЕССТРАЦІЇ ПРАВА ВЛАСНОСТІ НА ІННОВАЦЙНИЙ ПРОДУКТ}

Анотація. Об’єкти інтелектуальної власності є рушійною силою в розвитку науки та технологій. Актуалізовано проблематику обліку об'єктів інтелектуальної власності у контексті привласнення авторства на чужі розробки та застосування ефективних засобів захисту інноваційного продукту в умовах недобросовісної конкуренції. Основним завданням активізації інноваційного розвитку підприємства є формування його обліково-аналітичного забезпечення, яке повинно сприяти розширенню можливостей формування та використання їхнього інноваційного потенціалу, саме тому робота є актуальною та своєчасною.

Метою статті є систематизація теоретичних положень щодо реєстрації права власності та обгрунтування практичних рекомендацій щодо обліку патентування.

Систематизовано рахунки бухгалтерського обліку та типові проведення, що можуть використовуватись при купівлі-продажу ліцензій. Проведено аналіз впроваджених інновацій та виданих патентів. Виявлено причини зменшення кількості зареєстрованих об’єктів інтелектуальної власності, а саме: зменшення кількості осіб, що здійснюють дослідницьку діяльність та недостатній рівень умов і фінансування науково-технічної та інноваційної діяльності. Зосереджено увагу на ноу-хау як об'єкті нематеріального активу та систематизовано основні форми документального підтвердження введення та вибуття об'єкту НА.

У даній роботі використано такі методи як: системний підхід, економіко-статистичний аналіз, класичні статистичні методи, методи аналізу та синтезу.

Сформовано методичні рекомендації щодо обліку патентів. Основні положення яких полягають в такому: щорічний збір за підтримку патенту відносимо до витрат майбутнього період та щокварталу списуємо на рахунок відповідних витрат періоду; для амортизації вартості патенту застосовують прямолінійний метод, 
зокрема строк корисного використання буде дорівнювати строку дії самого патенту; продаж або придбання товарів обліковується на рахунку “Необоротні активи та групи вибуття, утримувані для продажу”; плата за використання об’єкта інтелектуальної власності, тобто роялті не оподатковується ПДВ.

Ключові слова. Інтелектуальна власність, винахід, корисна модель, ноу-хау, патентування, ліцензія.

Problem solving. In the modern world intellectual property is demanded in all spheres of public life. The world economy is at the forefront of intangible assets, i.e. new knowledge, ideas, inventions, discoveries, useful models. The rapid development of science and technology requires every enterprise to create a special research department. Every day in Ukraine there is an increasing number of organizations, whose activities are aimed at implementation of research projects. New innovative products of small and medium-sized businesses are entering the world market.

In connection with the development and implementation of the object of intellectual property, relations of a legal nature arise. Accounting and analytical support of innovation activity process is a necessity of time which should help to expand opportunities of formation and use of innovative potential of enterprise.

Analysis of recent research and publications. Such national scientists as Tuchin L. [6], FatenokTkachuk A. [7], Yurkiv R. [9] have made a significant contribution to the research of methodology and principles of construction of accounting of objects of innovative activity. The issue of accounting support for the registration of intellectual property rights needs additional attention.

Purpose and tasks of the article. The purpose of this article is development and systematization of theoretical provisions and substantiation of practical recommendations on accounting and analytical support of procedure of registration of intellectual property right on innovation product.

Presentation of the basic material and substantiation of the obtained research results. According to the Economic Code of Ukraine, the innovation product is the result of the innovation project implementation and research and development of new technology or products with the production of experimental sample or research party [1]. According to NASP 8 "Non-thematic assets" notes that development is application of the results of researches and other knowledge by the enterprise for planning and designing new or significantly improved materials, devices, products, processes, systems or services before the beginning of their serial production or use [2]. Also in this provision the classification of innovations as intangible assets under the following groups is given:

- rights to industrial property objects (inventions, utility models, industrial designs, plant varieties, animal species, know-how, protection from unfair competition, rationalisator proposal);

- rights to copyright and related rights objects (computer program, scientific and technical information);

- rights to trademarks and services (trademark, company name).

A special subject of intellectual property is know-how, which is considered as a certain combination of knowledge: Technical, technological and commercial, which is drawn up in the form of a document, skills or experience, which is not patented. As an object of intellectual property know-how has the following features: Non-material form, confidentiality of information, absence of official recognition of the security and state registration.

Standard forms of documentation are used for primary accounting: An act of introduction into the commercial turnover of the object of intellectual property rights in the composition of intangible assets (typical form № A-1); Inventory card of the object of intellectual property rights in the composition of intangible assets (typical form № A-2); Act of disposal (liquidation) of the object of intellectual property rights in the composition of intangible assets (typical form № A-3).

The accrual of depreciation on an intellectual property object is reflected in the information of accounting of intangible assets and calculation of amortization (the default form of SPA-1). When the 
enterprise receives know-how, video, audio, or written confirmation of the contents of confidential information is also added. In addition to the original documentation, the enterprise must have special documents confirming the ownership of the given objects (patent, license, certificate, contract of use, etc.).

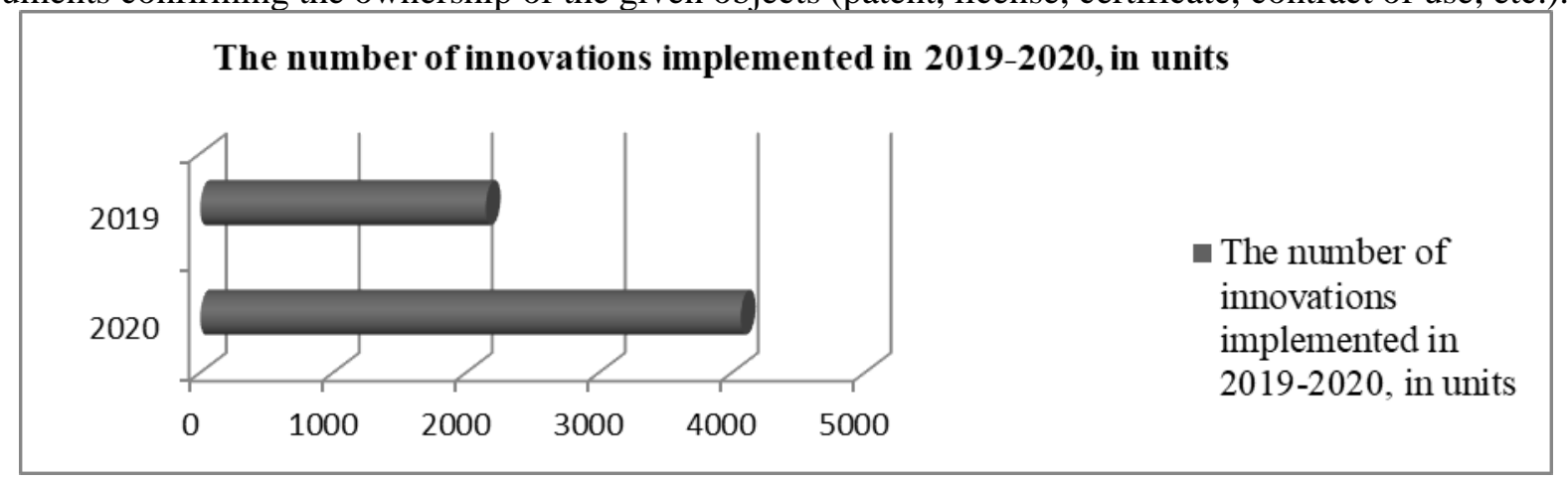

Fig. 1. Number of innovations implemented in 2020

Source: Developed by source [3]

In 2019, 2148 units of innovative products were introduced, of which new machines, equipment and devices make up 760 units and 2318 units of new technological processes, of which 857 are low-waste and energy-efficient. As we see in Fig.1. in 2020, the volume of innovations implemented increased significantly, in particular by 1918 . or $89,3 \%$. In turn, the situation in terms of innovation implementation has improved considerably. In 2019, the volume of innovation products sold amounted to UAH 34264,9 million, which is UAH 13261,3 million. less than in 2020.

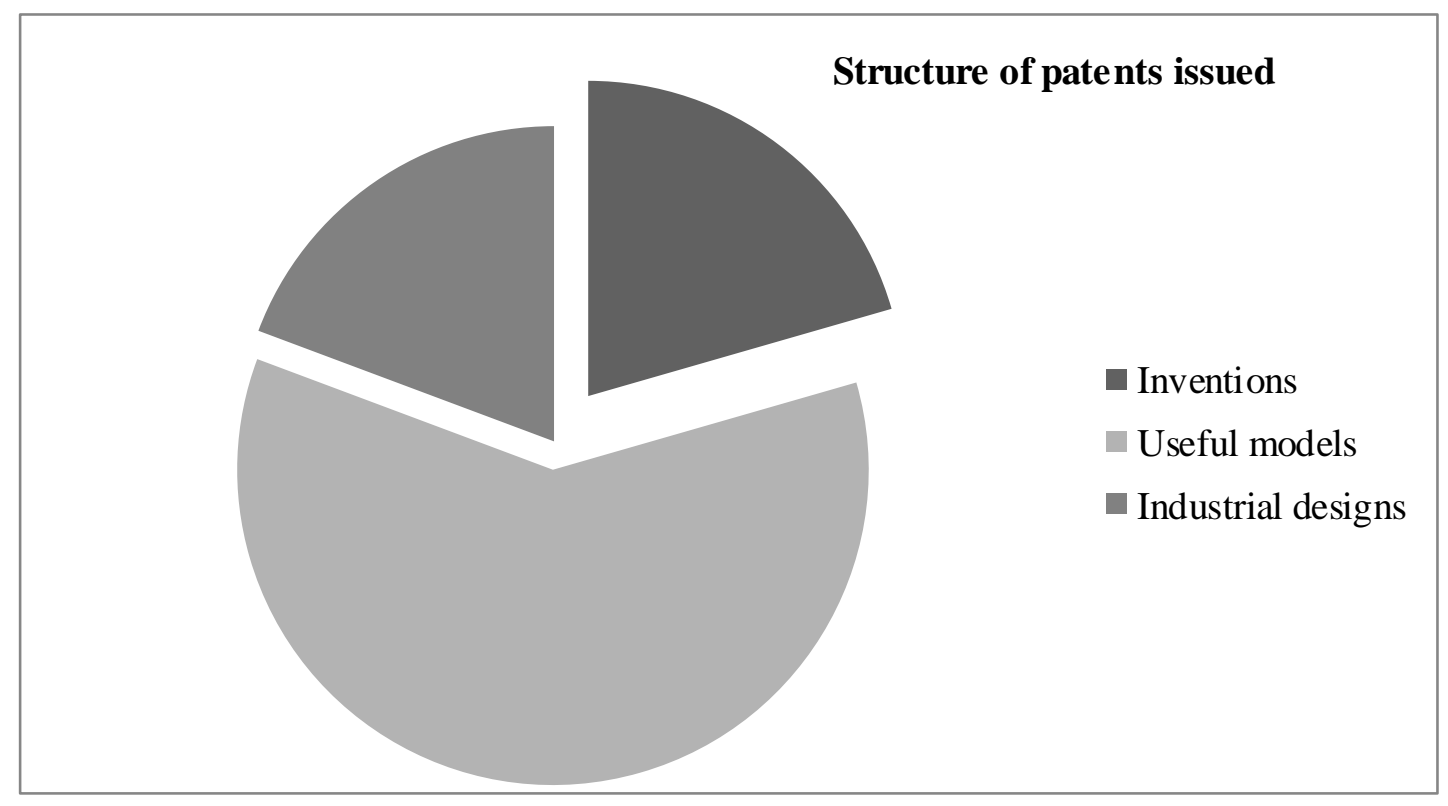

Fig. 2. The structure of patents issued in 2020

Source: Developed by source [5]

Intangible assets are most subject to borrowing during unfair competition. Once an innovative product is developed, it is important to patent it on time. A document that confirms the existence of ownership of objects such as invention and useful model is called a patent. Only an individual who is the author of the invention or the enterprise, provided that the invention is official, can register the object of intellectual 
property. By order of the Ministry of Education and Science of Ukraine dated 22/01/2001. according to № 2 , the procedure of drawing up and submitting an application for registration of the invention is provided. The legal protection on the object of intellectual property is provided on condition [4]:

1) the invention or useful model does not contradict the public order, meets the principles of humanity and morality;

2) the invention or utility model is new and ready for use;

3) the output has a certain level of output;

4) the object of the invention or utility is a product, process, or new application of a known product or process.

As of November 1, 2021, 631033 objects of intellectual property have been registered since 1992: 129568 inventions; 149269 useful models; 44475 industrial designs; 307721 brand with separate registrations. In particular, in 2020 the structure of patents issued is dominated by industrial designs $-60 \%$ of the total number of patents issued, in the second place inventions $-21 \%$, and the rest $19 \%$ is on useful models (Fig.2).

In 2020, 2179 patents were issued for inventions, 1086 (49,8\%) for national applicants, the rest for foreign applicants, in particular 265 for applicants from the USA, 136 for Germany, 118 for Schweitsiria, 61 for France, 50 for Japan, 45 - Great Britain, 44 - Luxembourg, 37 - China, 35 - Italy and the Netherlands, and 30 - Russian Federation. In total, registered patents decrease by 15,9\% in 2020 compared to 2017 (Fig. $3)$.

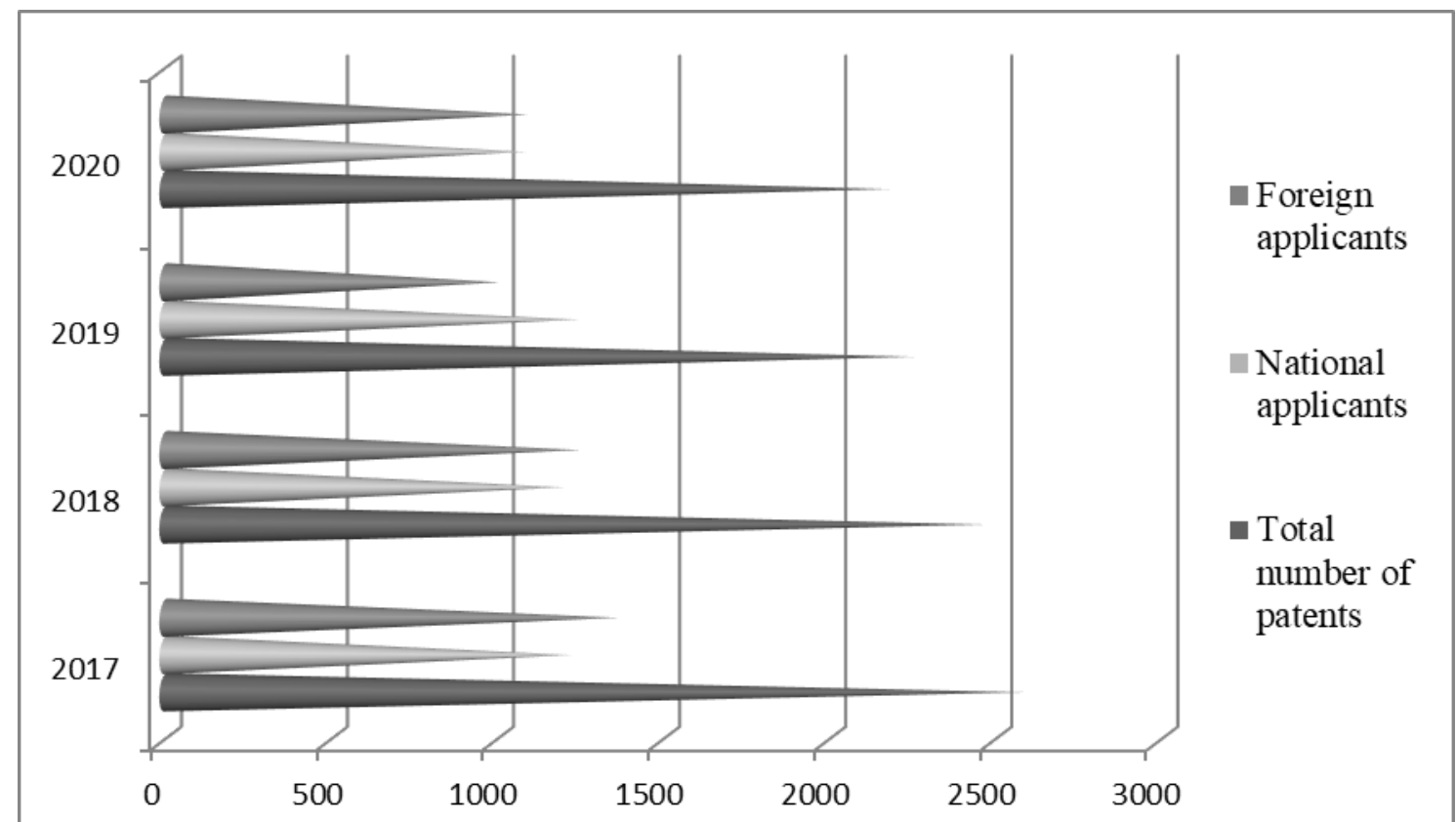

Fig. 3. The dynamics of the issue of patents for inventions from 2017 to 2020

Source: Developed by the author on the basis of the source [5].

The reasons for decreasing the number of registered intellectual property objects may be:

1) reduction of number of researchers and inventors;

2) insufficient conditions for invention activity;

3) insufficient level of state financing of scientific, technical and innovation activity;

4) lack of full information base on innovation projects.

In the process of development of invention and further registration of ownership rights for it all expenses forming the initial value of intangible assets, collect for subbrahun 154 "Acquisition (creation) of intangible assets". When the object of intangible assets is put into operation, all accumulated expenses are 
written off by the correspondent of DT 124 "Industrial property rights" - KT 154. The main patent wiring is shown in Fig. 4.

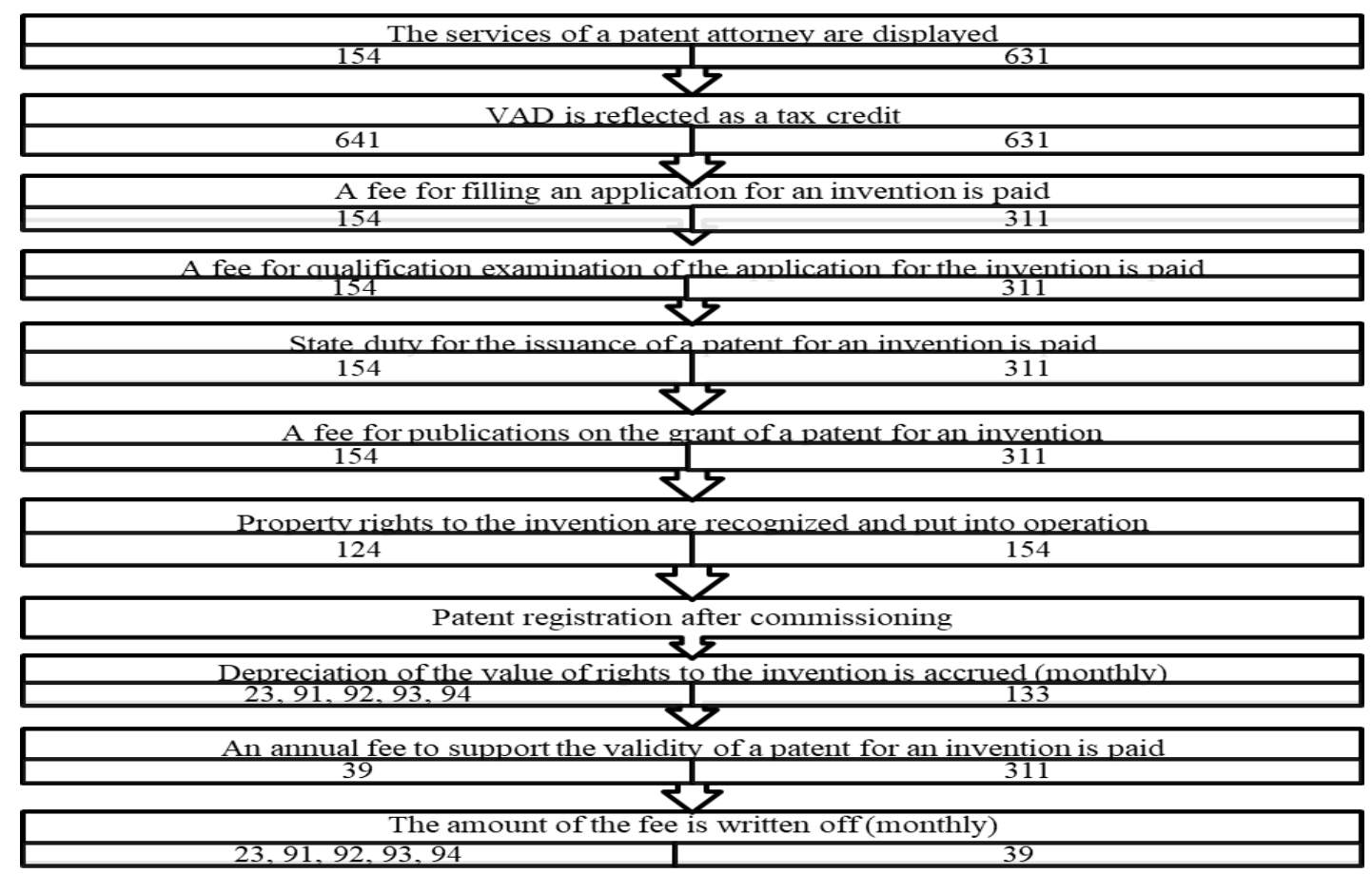

Fig. 4 The basic wiring at patent invention

Source: Developed by author based on source analysis $[6 ; 8 ; 9]$.

The company may transfer the rights to intellectual property objects or the right to use this object to another person, which is sold as a license, having possession of a patent or certificate.

\begin{tabular}{|c|c|}
\hline & $\begin{array}{l}\text {-Accounting for the implementation of exclusive } \\
\text { licenses }\end{array}$ \\
\hline $\begin{array}{c}\text { DT } 122 \\
\text { KT } 123,124,125,127\end{array}$ & $\begin{array}{l}\text {-It was made a decision to exercise exclusive } \\
\text { rights to object of intellectual property }\end{array}$ \\
\hline $\begin{array}{l}\text { DT } 972 \\
\text { CT } 122\end{array}$ & - A license contract is concluded \\
\hline $\begin{array}{c}\text { DT } 31 \\
\text { KT } 377(361)\end{array}$ & -Payment was received according to the contract \\
\hline & $\begin{array}{l}\text { - Accounting for the acquisition of exclusive } \\
\text { licenses }\end{array}$ \\
\hline $\begin{array}{l}\text { DT } 122 \\
\text { KT } 631\end{array}$ & - Acquired exclusive rights to the property object \\
\hline $\begin{array}{c}\text { DT0411 } \\
\text { KT - }\end{array}$ & $\begin{array}{l}\text { - Acquired exclusive rights on the terms of royalty } \\
\text { payment }\end{array}$ \\
\hline $\begin{array}{l}\text { DT Expense account } \\
\text { KT } 133\end{array}$ & -Depreciation is displayed \\
\hline $\begin{array}{l}\text { DT133 } \\
\text { KT } 122\end{array}$ & -Expiration of the contract \\
\hline $\begin{array}{c}\text { DT - } \\
\text { KT } 0411\end{array}$ & $\begin{array}{l}\text {-Expiration of the contract if the object is } \\
\text { accounted for off-balance sheet }\end{array}$ \\
\hline
\end{tabular}

Fig. 5. Accounting of exclusive licenses

Source: developed by author based on source analysis [6;8;9].

Methodological recommendations on accounting of intangible assets indicate that the license is 
recognized as an intangible asset if its duration is more than one year but less than one operating cycle. Scientists' opinions on this issue have somewhat divided: Some argue that non-exclusive licenses need to be recorded as operational lease, while the only ones - as intangible assets, others adhere to the idea that the cost of licenses should be included in the costs of the enterprise [8].

The taking on the balance and realization of licenses is given in figures 5. and 6 .

\begin{tabular}{|c|c|}
\hline & $\begin{array}{l}\text {-Accounting for the implementation of non- } \\
\text { exclusive licenses }\end{array}$ \\
\hline $\begin{array}{c}\text { DT } 122 \\
\text { KT } 123,124,125,127\end{array}$ & $\begin{array}{l}\text {-It was made a decision to exercise non-exclusive } \\
\text { rights to object of intellectual property }\end{array}$ \\
\hline $\begin{array}{l}\text { DT } 949 \\
\text { KT } 1331\end{array}$ & -The amount of monthle depreciation is reflected \\
\hline $\begin{array}{c}\text { DT 31 } \\
\text { KT } 377(361)\end{array}$ & -Payment was received according to the contract \\
\hline & - Accounting for purchased non-ezclusive licenses \\
\hline $\begin{array}{l}\text { DT } 01 \\
\text { KT - }\end{array}$ & -Purchased a license \\
\hline $\begin{array}{l}\text { DT - } \\
\text { KT } 01\end{array}$ & - License expired \\
\hline
\end{tabular}

Fig. 6. Accounting of non-exclusive licenses

Source: developed by author based on source analysis [6;8;9].

Provided that the licensor receives only the right to use the intellectual property object, the registration of the obtained license is carried out outside the balance, as its value cannot be determined in a reliable way, in turn the licensor accounts for 12 "Non-themed assets". When purchasing exclusive rights, the object of intellectual property corresponds to all attributes of intangible assets.

Conclusions and prospects of further research. The article systematized and summarized the accounting procedures during registration of ownership of the innovation product the conditions and peculiarities of carrying out of the patent process are given. The state of patenting has been analyzed, in particular, the main reasons for the reduction of patented inventions have been identified. The object of intellectual property know-how in the structure of intangible assets has been investigated. As a result of our work we have developed methodological recommendations concerning the registration of patents: annual fee for patent support is charged to the expenses of the future period and is written off quarterly at the expense of the corresponding expenses of the period; to amortize the cost of a patent apply a direct-lightning method, in particular the term of useful use will equal the term of validity of the patent itself; sale or purchase of goods is recorded on the account 286 "Non-current assets and sales groups held for sale"; the fee for the use of the object of intellectual property, that is, royalties are not taxed by VAT.

\section{Джерела та література}

1. Господарський кодекс України. Верховна рада Украӥни: веб-сайт. URL: https://zakon.rada.gov.ua/laws/show/40-15\#Text (дата звернення : 27.11.2021).

2. Національниий стандарт бухгалтерського обліку 8 «Нематеріальні активи». Верховна рада Украӥни: веб-сайт. URL: https://zakon.rada.gov.ua/laws/show/z0750-99\#Tехt (дата звернення : 27.11.2021).

3. Статистичний щорічник України за 2020 рік. Державна служба статистики Украӥни. 2020. URL: http://ukrstat.gov.ua/druk/publicat/kat_u/publ1_u.htm (дата звернення: 27.11.2021).

4. Постанова «Про затвердження Правил складання і подання заявки на винахід та заявки на корисну 
модель». Верховна рада України: веб-сайт. URL: https://zakon.rada.gov.ua/laws/show/z0173-01\#Text (дата звернення : 27.11.2021).

5. Річний звіт за 2020 рік. Украйнський інститут інтелектуальноӥ власності. 2020. URL: https://ukrpatent.org/uk/articles/statistics (дата звернення: 27.11.2021).

6. Тучин Л. Я. Майнові права інтелектуальної власності як внесок до статутного капіталу господарських товариств: дис.. к. ю. наук: доктора філософії. Львів. нац. ун-т. ім. I. Франка. Львів, 2020. 207 с. URL: https://law.lnu.edu.ua/wp-content/uploads/2020/06/DYSERTATSIYA-TURCHYN-04.06.2020.pdf (дата звернення: 27.11.2021).

7. Фатенок-Ткачук А. О., Кулинич М. Б., Сафарова А. Т. Обліково-аналітичне забезпечення інноваційної діяльності підприємства : монографія. Луцьк : Вежа-Друк, 2019. 154 с.

8. Фатенок- Ткачук А.О. Облікове забезпечення процедур реєстрації права власності на продукт інноваційної діяльності. Актуальні проблеми інноваційного розвитку України: теорія, методологія, практика: 2014 рік: матеріали XVI Міжнар. наук.-практ. конф., 29-30 трав. 2014 р. Луцьк: Вежа-Друк, 2014. С.255-258.

9. Юрків Р. Перспективи розвитку та адаптації до стандартів європейського союзу законодавства України щодо примусового ліцензування прав на винаходи (корисні моделі). Вісник Львівського університету. 2020. № 71. URL: https://law.lnu.edu.ua/news/vyyshov-u-svit-71-vypusk-fakul-tets-koho-vydannia-visnyk-1-vivskoho-universytetu-seriia-iurydychna (дата звернення 27.11.2021р.).

\section{References}

1. Ghospodarsjkyj kodeks Ukrajiny.[Commercial Code Ukraine]. Verkhovna rada Ukrajiny. Retrieved from: https://zakon.rada.gov.ua/laws/show/40-15\#Text[in Ukrainian].

2. Nacionaljnyyj standart bukhghaltersjkogho obliku 8 «Nematerialjni aktyvy» [National accounting standard provision 8 "Intangible assets"]. Verkhovna rada Ukrajiny. Retrieved from: https://zakon.rada.gov.ua/laws/show/z0750-99\#Text[in Ukrainian].

3. Statystychnyj shhorichnyk Ukrajiny za 2020 rik [Statistical Yearbook of Ukraine for 2020]. Derzhavna sluzhba statystyky Ukrajiny. Retrieved from: http://ukrstat.gov.ua/druk/publicat/kat_u/publ1_u.htm[in Ukrainian].

4. Postanova «Pro zatverdzhennja Pravyl skladannja i podannja zajavky na vynakhid ta zajavky na korysnu modelj». [Resolution «On approval of the Rules for drawing up and submitting an application for an invention and an application for a utility model»]. Verkhovna rada Ukrajiny. Retrieved from: https://zakon.rada.gov.ua/laws/show/z0173-01\#Text [in Ukrainian].

5. Richnyj zvit za 2020 rik [Annual report for 2020]. Ukrajinsjkyj instytut intelektualjnoji vlasnosti.. Retrieved from: https://ukrpatent.org/uk/articles/statistics[in Ukrainian].

6. Tuchyn L. Ja. (2020). Majnovi prava intelektualjnoji vlasnosti jak vnesok do statutnogho kapitalu ghospodarsjkykh tovarystv [Intellectual property rights as a contribution to the authorized capital of companies]. Doctor's thesis. Lviv. LNU. Retrieved from: https://law.lnu.edu.ua/wp-content/uploads/2020/06/DYSERTATSIYATURCHYN-04.06.2020.pdf [in Ukrainian].

7. Fatenok-Tkachuk A. O., Kulynych M. B., Safarova A. T. (2019). Oblikovo-analitychne zabezpechennya innovatsiynoyi diyal'nosti pidpryyemstva [Accounting and analytical support of innovative activity of the enterprise]. Lutsk: Tower-Print [in Ukrainian].

8. Fatenok-Tkachuk A.(2014). Oblikove zabezpechennja procedur rejestraciji prava vlasnosti na produkt innovacijnoji dijaljnosti [Accounting support of procedures for registration of ownership of a product of innovative activity]. Aktualni problemy innovacinogho rozvytku Ukrainy: teoria, metodologhia, praktyka: materialy Mizhnarodnoyi naukovo-praktychnoyi konferentsiyi (pp. 255-258). Lutsk: Tower-Print [in Ukrainian].

9. Jurkiv R. (2020). Perspektyvy rozvytku ta adaptaciji do standartiv jevropejsjkogho sojuzu zakonodavstva Ukrajiny shhodo prymusovogho licenzuvannja prav na vynakhody (korysni modeli) [Prospects for the development and adaptation to the standards of the European Union of the legislation of Ukraine on compulsory licensing of rights to inventions (utility models)]. Visnyk Ljvivsjkogho universytetu. $71 . \quad$ Retrieved from:https://law.lnu.edu.ua/news/vyyshov-u-svit-71-vypusk-fakul-tets-koho-vydannia-visnyk-1-vivs-kohouniversytetu-seriia-iurydychna[in Ukrainian]. 